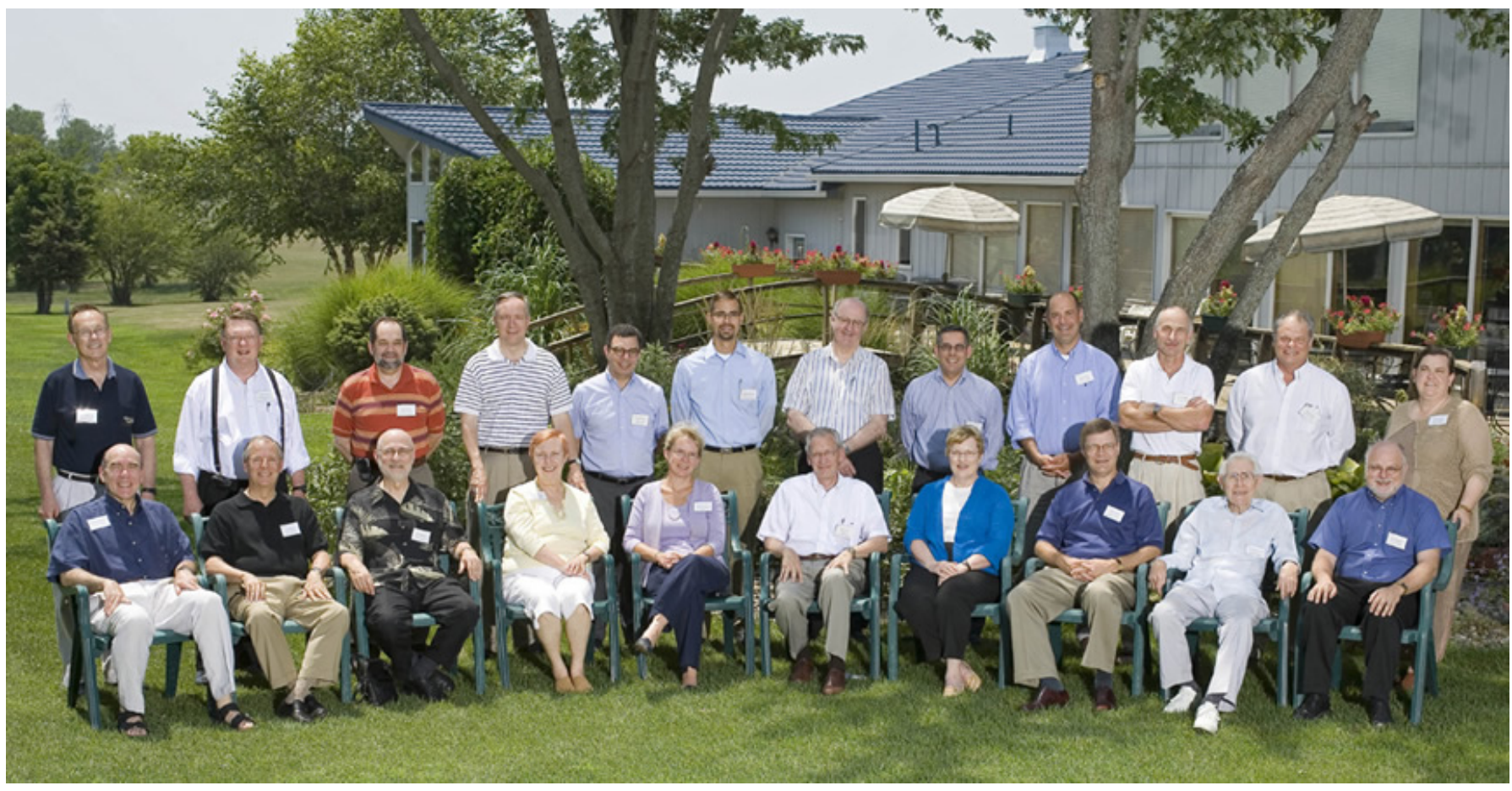

standing, left to right: John Brighton, Donald Weeks, Ron Trewyn, Duane Nellis, Richard Barohn, Jeremy Anderson, Brian Foster, Jeff Aube, Keith Yehle, Chris Sorensen, Mike Nichols, Sally Hayden seated, left to right: Richard Lariviere, Jim Roberts, Bob Barnhill, Barbara Atkinson, Kim Espy, John Wiley, Mabel Rice, Steve Warren, Dick Schiefelbusch, Joe Steinmetz

conference photo by Earl Richardson 


\section{CONFERENCE PARTICIPANTS 2006}

\section{Keynote Speaker}

John D. Wiley, Ph.D., Chancellor, University of Wisconsin-Madison

Iowa State University

John Brighton, Ph.D., Vice Provost for Research

\section{Kansas State University}

M. Duane Nellis, Ph.D., Provost and Professor

Christopher Sorensen, Ph.D., University Distinguished Professor, Dept. of Physics

Ron Trewyn, Ph.D., Vice Provost/Dean

\section{The University of Kansas}

Barbara Atkinson, M.D., Executive Vice Chancellor, KU Medical Center

Jeff Aubé, Ph.D., Professor, Medicinal Chemistry

Richard Barohn, M.D., Professor and Chair, Neurology Dept., KU Medical Center

Robert Hemenway, Ph.D., Chancellor

Richard Lariviere, Ph.D., Provost and Executive Vice Chancellor

Mabel L. Rice, Ph.D., The Fred \& Virginia Merrill Distinguished Professor of

Advanced Studies and Director of the Merrill Center

Jim Roberts, Ph.D., Vice Provost for Research and President, KU Center for Research

Richard Schiefelbusch, Ph.D., Director Emeritus of the Schiefelbusch Institute for Life Span Studies and the Merrill Center, and Merrill Board member

Joseph Steinmetz, Ph.D., Dean of the College of Liberal Arts and Sciences

Steven F. Warren, Ph.D., Director, Schiefelbusch Institute for Life Span Studies, and

Merrill Board member

Keith Yehle, Director of Government Relations

\section{University of Missouri}

Brian Foster, Ph.D., Provost

Michael F. Nichols, Ph.D., Director, Office of Technology Management \& Industry Relations

\section{University of Nebraska - Lincoln}

Kimberly Andrews Espy, Ph.D., Associate Vice Chancellor for Research

Donald P. Weeks, Ph.D., Professor and Head, Biochemistry Department

\section{Other Participants}

Jeremy Anderson, Office of the Governor of Kansas

Robert E. Barnhill, Ph.D., Vice Chancellor for Research and Technology Transfer, The University of Texas System, and Merrill Board member

Reggie Robinson, J.D., President and CEO, Kansas Board of Regents Jean Schődorf, Ph.D., Kansas State Senator 